\title{
Effects of simulated weightlessness on cellular morphology and biological characteristics of cell lines SGC-7901 and HFE-145
}

\author{
M. Zhu' ${ }^{1}$ X.W. Jin ${ }^{1}$, B.Y. Wu' ${ }^{2}$ J.L. Nie ${ }^{3}$ and Y.H. $\mathbf{L i}^{3}$ \\ ${ }^{1}$ Department of Gastroenterology, Air Force General Hospital of PLA, \\ Beijing, China \\ ${ }^{2}$ Department of Gastroenterology, South Building, \\ Chinese PLA General Hospital, Beijing, China \\ ${ }^{3}$ The 13th Laboratory of Institute of Space Medico-Engineering, Beijing, China \\ Corresponding author: M. Zhu \\ E-mail: mingzhucn@126.com
}

Genet. Mol. Res. 13 (3): 6060-6069 (2014)

Received June 21, 2013

Accepted January 10, 2014

Published August 7, 2014

DOI http://dx.doi.org/10.4238/2014.August.7.20

\begin{abstract}
We investigated the effects of simulated weightlessness on cellular morphology, proliferation, cell cycle, and apoptosis of the human gastric carcinoma cell line SGC-7901 and the human gastric normal cell line HFE-145. A rotating clinostat was used to simulate weightlessness. The Image-Pro4.5 image analysis system was used for morphometric analysis. Proliferating cell nuclear antigen expression was examined by immunohistochemical staining. Changes in the cell cycle were examined using a cytometer. Apoptosis was measured using the terminal dUTP nick-end labeling (TUNEL) method. When subjected to simulated weightlessness, the cellular morphology of SGC-7901 cells was changed at $12,24,48$, and $72 \mathrm{~h}$, cell conversion from the $\mathrm{G}_{1}$ to $\mathrm{S}$ phase was blocked, proliferation was inhibited at 48 and $72 \mathrm{~h}$, and the apoptosis index was increased at $72 \mathrm{~h}$. The same changes were observed for HFE-145 cells at $12 \mathrm{~h}$ when subjected to simulated weightlessness, but no significant changes were found
\end{abstract}


afterward compared with controls. SGC-7901 cells change their cellular morphology and biological characteristics during clinostat-simulated weightlessness at $72 \mathrm{~h}$, but HFE- 145 cells only change at $12 \mathrm{~h}$ and adapt to simulated weightlessness after that point.

Key words: Simulated weightlessness; Gastric cancer cells; Gastric normal cells; Cell morphology; Biological characteristics

\section{INTRODUCTION}

Space flight may cause some physiological changes in organisms, including cephalic fluid shifts, loss of fluid and electrolytes, loss of muscle mass, space motion sickness, anemia, reduced immune response, and loss of calcium and mineralized bone (Hughes-Fulford, 2001). Although the influence of weightlessness on the tissues of organic bodies is relatively clear, the reaction of cells requires investigation. Diagnosing and treating tumors are current challenges in the medical field. In particular, it is unknown whether tumor cell activity is similar under normal gravity and weightlessness conditions. Few studies have been conducted to examine gastric cancer cells and gastric normal cells under weightlessness or simulated weightlessness conditions. Clinostats are instruments that can be used to simulate ground weightlessness and have been applied for unicellular organism experiments (Klaus, 2001). The application of clinostats for weightlessness simulation enables observation of the biocharacteristics of gastric cancer cells from a new perspective and exploration of the laws of cellular initiation and development, which may provide revelatory clues for tumor treatment.

In this study, we used a rotating clinostat to simulate weightlessness to observe the effects on the cellular morphology and biological characteristics of the gastric cancer cell line SGC-7901 and the gastric normal cell line HFE-145.

\section{MATERIAL AND METHODS}

\section{Cell culture}

The human gastric carcinoma cell line SGC-7901 was preserved by our laboratory and the gastric mucosa cell line HFE-145 was kindly provided by Dr. Zhi-Qiang Xiao from the Institute of Tumor Investigation of the First Military Medicine University. Twenty milliliters of cell culture was inoculated per cell culture flask. Cover glasses were attached to the bottom of the flasks for hematoxylin and eosin staining, and proliferating cell nuclear antigen (PCNA) antibody was detected. Apoptosis was measured using the terminal dUTP nick-end labeling (TUNEL) method; the cell density was $2 \times 10^{5} /$ flask. Five milliliters of Dulbecco's modified Eagle's medium (DMEM) containing $100 \mathrm{~mL} / \mathrm{L}$ calf serum, $100 \mathrm{U} /$ $\mathrm{mL}$ penicillin, $100 \mu \mathrm{g} / \mathrm{mL}$ streptomycin, and $50 \mathrm{~g} / \mathrm{L}$ sodium bicarbonate was used as the culture medium for cell growth. The $\mathrm{pH}$ was adjusted to 7.2. When all cells had attached to the flask walls after $24 \mathrm{~h}$, the flasks were filled with culture medium. Flasks were airproofed after removing the air. Next, the flasks were randomly and equally divided into 2 groups. One group was placed on the clinostat at $30 \mathrm{rpm}$ (MG3 type; Institute of Biophysics, Chinese Academy of Sciences, Beijing, China) in a culture box at $37^{\circ} \mathrm{C}$, and the other group was incubated at $37^{\circ} \mathrm{C}$ under standard conditions. 


\section{Morphometric study after clinostat-simulated weightlessness}

After 12, 24, 36, 48, and $72 \mathrm{~h}$ of simulated weightlessness, cover glasses were removed from a flask for each condition, the samples were rinsed in $\mathrm{pH} 7.4$ phosphate-buffered saline (PBS) for $5 \mathrm{~min}$, and the cells were fixed using 4\% paraformaldehyde for $30 \mathrm{~min}$. Cover glasses were stained using hematoxylin for $1 \mathrm{~min}$ and eosin for $2 \mathrm{~min}$. The cells were then dehydrated using gradient ethyl alcohol, hyalinized by dimethylbenzene, and enveloped by neutral resin.

The Image-Pro Plus 4.5 image analysis system (Media Cybernetics; Rockville, MD, USA) was employed for morphometric study. The area and ratio of the long and short diameter of the cells were measured.

\section{PCNA expression}

After 12, 24, 36, 48, and $72 \mathrm{~h}$ of simulated weightlessness, we removed the cover glasses from 6 flasks of SGC-7901 cells and 5 flasks of HFE-145 cells, rinsed the samples in $\mathrm{pH} 7.4$ PBS for $5 \mathrm{~min}$, and fixed the cells using $70 \%$ ethyl alcohol for $30 \mathrm{~min}$. After rinsing with PBS, we examined PCNA expression using an immunostaining procedure. First, $0.3 \%$ hydrogen peroxide was added for $10 \mathrm{~min}$. Normal goat serum was used for blocking for 30 min. The mouse anti-PCNA monoclonal antibody PC-10 (DAKO A/S and Cytomation, Inc., Copenhagen, Denmark) was diluted 1:300 and incubated with the cells overnight at $4^{\circ} \mathrm{C}$. PV9000 reagent 1 was added for 30 min at $37^{\circ} \mathrm{C}$, and PV-9000 reagent 2 was added for $1 \mathrm{~h}$ at $37^{\circ} \mathrm{C}$. Next, the cover glasses were treated with diaminobenzidine (DAB) and stained with hematoxylin for 3 min. Finally, cells were dehydrated using an ethyl alcohol gradient, hyalinized using dimethylbenzene, and enveloped by neutral resin. Normal rabbit serum was diluted to the same concentration as the first antibody as a negative control.

PCNA-positive staining located in the nucleolus appeared as a brown color, while a negative result did not. The results were analyzed by counting the positive cells under a microscope.

\section{Cell cycle analysis}

After 12, 24, 36, 48, and $72 \mathrm{~h}$ of simulated weightlessness, 6 flasks of SGC-7901 cells and 5 flasks of HFE-145 cells were used for cell digestion by trypsin. Digested cells were collected by centrifugation. The cells were maintained at $4^{\circ} \mathrm{C}$ in a refrigerator for at least $24 \mathrm{~h}$ in $70 \%$ cold ethyl alcohol. Cells were collected after centrifugation (1500 rpm for $5 \mathrm{~min}$ ). After rinsing with PBS, the cells were incubated with ribonuclease A (RNaseA) for $30 \mathrm{~min}$. Cells were then stained with $50 \mathrm{mg} / \mathrm{L}$ propidium iodide for $30 \mathrm{~min}$. Cell cycle was examined using a cytometer (FACSCalibur; BD Biosciences, Franklin Lakes, NJ, USA).

\section{Apoptosis measurement}

After 12, 24, 36, 48, and $72 \mathrm{~h}$ of simulated weightlessness, 6 flasks of SGC-7901 cells and 5 flasks of HFE-145 cells were used for analysis. Cover glasses were removed from the flask and rinsed with $\mathrm{pH} 7.4 \mathrm{PBS}$ for $5 \mathrm{~min}$, followed by fixation in 4\% paraformaldehyde for $30 \mathrm{~min}$. After rinsing with PBS, SGC-7901 cells were treated with $0.1 \%$ Triton X100 for 25 min and HFE-145 cells were treated with $15 \mu \mathrm{g} / \mathrm{mL}$ protease K for $35 \mathrm{~min}$. Subsequent steps were performed accord- 
ing to manufacturer instructions. First, we added $0.3 \% \mathrm{H}_{2} \mathrm{O}_{2}$ (dissolved in carbinol) at $20^{\circ} \mathrm{C}$ for 30 min, rinsed the cells with PBS, and dried the cell samples. Next, we added TUNEL reactant at $37^{\circ} \mathrm{C}$ for $60 \mathrm{~min}$ in a damp box, $3 \%$ calf serum at $37^{\circ} \mathrm{C}$ for $30 \mathrm{~min}$, color-developing reacting agent at $37^{\circ} \mathrm{C}$ for $45 \mathrm{~min}$, and color-developing agent at $20^{\circ} \mathrm{C}$ for $20 \mathrm{~min}$ in a cassette. Finally, cells were stained with nuclear fast red. A negative control without TUNEL reactant was also used.

Apoptotic cells showed an amethyst and contracted nucleolus, while negative cells showed a pink nucleolus. The cytoplasm was not heavily stained. The results were analyzed by counting the positive cells under a microscope.

\section{Statistical analysis}

The Stata 7.0 statistical analysis software (StataCorp; College Station, TX, USA) was used to analyze the measurements. The Student $t$-test was adopted to compare the results of average cell area and the ratio of long and short diameter and the percentages of PCNApositive cells, of each cell cycle phase, and of the apoptotic cells between the weightlessness group and the control group. Statistical significance was considered to be positive at $\mathrm{P}<0.05$.

\section{RESULTS}

\section{Change in cell morphology after simulated weightlessness}

Compared with the control, the area of cell line SGC-7901 decreased significantly over time when subjected to simulated weightlessness (Table 1; P $<0.01$ ). The ratio of the long to short diameters increased significantly after $36 \mathrm{~h}$ of simulated weightlessness (Table $1 ; \mathrm{P}<0.01$ ), but did not change significantly for other time periods. The area of the cell line HFE-145 increased significantly after $12 \mathrm{~h}$ of simulated weightlessness (Table $1 ; \mathrm{P}<0.01$ ), but did not change significantly for other times. The ratio of long to short diameters did not change significantly over time.

\begin{tabular}{|c|c|c|c|c|c|c|c|}
\hline Cell & & Group & $12 \mathrm{~h}$ & $24 \mathrm{~h}$ & $36 \mathrm{~h}$ & $48 \mathrm{~h}$ & $72 \mathrm{~h}$ \\
\hline \multirow[t]{4}{*}{ SGC-7901 (N = 33-86) } & Area $\left(\mu \mathrm{m}^{2}\right)$ & Control & $66.6 \pm 3.13$ & $39.7 \pm 2.44$ & $53.4 \pm 3.33$ & $62.0 \pm 2.53$ & $74.8 \pm 3.37$ \\
\hline & Ratio of long to short diameter & Rotating & $34.5 \pm 1.21 *$ & $24.5 \pm 1.14^{*}$ & $39.8 \pm 2.19^{*}$ & $48.6 \pm 2.28 *$ & $33.0 \pm 2.86^{*}$ \\
\hline & & Control & $1.73 \pm 0.56$ & $1.64 \pm 0.37$ & $1.17 \pm 0.51^{*}$ & $1.78 \pm 1.36$ & $1.89 \pm 0.64$ \\
\hline & & Rotating & $1.84 \pm 0.60$ & $1.75 \pm 0.66$ & $1.87 \pm 1.02^{*}$ & $1.74 \pm 0.71$ & $2.13 \pm 1.05$ \\
\hline \multirow[t]{4}{*}{ HFE-145 ( $\mathrm{N}=35-102)$} & Area $\left(\mu \mathrm{m}^{2}\right)$ & Control & $43.6 \pm 1.68$ & $59.0 \pm 2.94$ & $44.6 \pm 2.70$ & $42.3 \pm 1.81$ & $89.7 \pm 5.35$ \\
\hline & Ratio of long to short diameter & Rotating & $62.2 \pm 3.46^{*}$ & $58.6 \pm 2.87$ & $38.3 \pm 2.42$ & $43.3 \pm 2.29$ & $96.4 \pm 4.76$ \\
\hline & & Control & $2.18 \pm 0.82$ & $2.04 \pm 0.76$ & $1.99 \pm 0.65$ & $1.71 \pm 1.03$ & $2.35 \pm 1.21$ \\
\hline & & Rotating & $2.09 \pm 0.89$ & $1.79 \pm 0.57$ & $2.25 \pm 1.03$ & $1.66 \pm 0.44$ & $2.87 \pm 1.78$ \\
\hline
\end{tabular}

Data are reported as means $\pm \mathrm{SD} . * \mathrm{P}<0.01$ vs control.

\section{PCNA expression after simulated weightlessness}

Compared with the control, PCNA expression in SGC-7901 cells did not change significantly after 12,24 , or $36 \mathrm{~h}$ of simulated weightlessness, but decreased significantly in the 48 and $72 \mathrm{~h}$ groups (Figure $1 \mathrm{~A}$ and $\mathrm{B}$, Table $2 ; \mathrm{P}<0.05$ and $\mathrm{P}<0.01$ ). PCNA expression in the 
HFE-145 cell line did not change significantly after $24,36,48$, and $72 \mathrm{~h}$ of simulated weightlessness, but decreased significantly in the $12 \mathrm{~h}$ group (Figure $2 \mathrm{~A}$ and $\mathrm{B}$, Table $2 ; \mathrm{P}<0.05$ ).

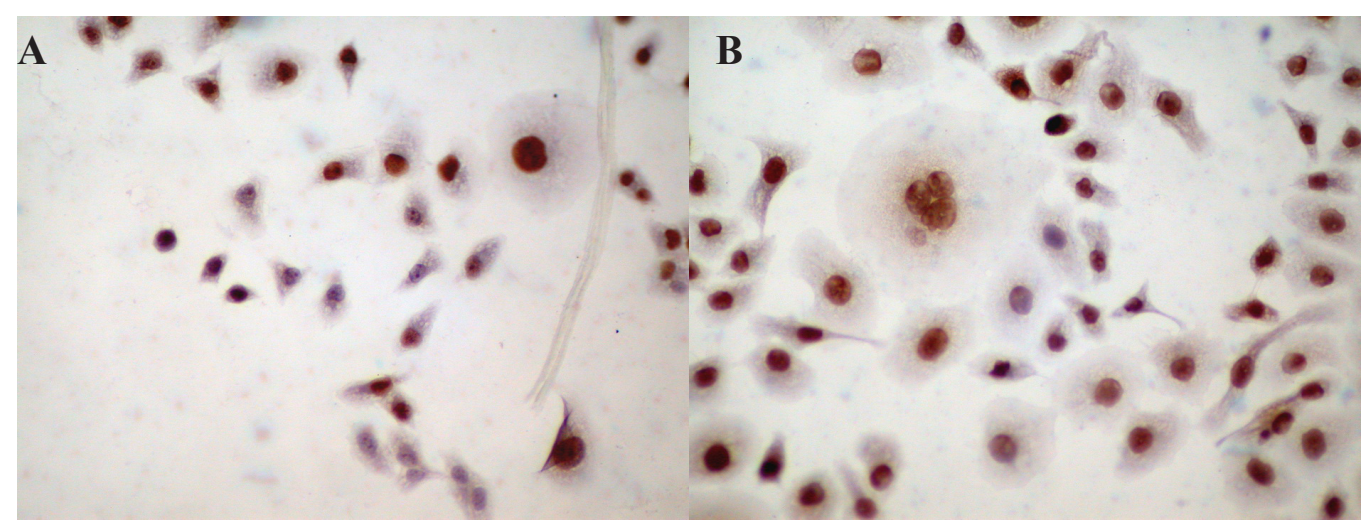

Figure 1. A. PCNA expression of SGC-7901: DAB dyeing: 48 h after simulated weightlessness (200X). B. PCNA expression of SGC-7901: DAB dyeing: $48 \mathrm{~h}$ in the control group (200X).

Table 2. Expressions of PCNA of SGC-7901 and HFE-145 cells during simulated weightlessness.

\begin{tabular}{llccccc}
\hline Cell & Group & \multicolumn{1}{c}{$12 \mathrm{~h}$} & $24 \mathrm{~h}$ & $36 \mathrm{~h}$ & $48 \mathrm{~h}$ & $72 \mathrm{~h}$ \\
\hline SGC-7901 $(\mathrm{N}=6)$ & Control & $92.0 \pm 1.09$ & $93.2 \pm 2.70$ & $97.0 \pm 0.93$ & $93.2 \pm 1.13$ & $95.1 \pm 1.95$ \\
& Rotating & $90.4 \pm 2.75$ & $94.1 \pm 1.32$ & $91.9 \pm 2.32$ & $87.1 \pm 2.17^{* *}$ & $86.0 \pm 1.56^{*}$ \\
HFE-145 (N=5) & Control & $13.8 \pm 1.58$ & $15.6 \pm 1.96$ & $16.6 \pm 2.95$ & $17.4 \pm 1.20$ & $20.2 \pm 5.08$ \\
& Rotating & $8.02 \pm 0.95^{* *}$ & $17.9 \pm 1.32$ & $11.8 \pm 1.95$ & $14.8 \pm 1.60$ & $14.4 \pm 2.74$ \\
\hline
\end{tabular}

Data are reported as means $\pm \mathrm{SD} . * * \mathrm{P}<0.05$ and $* \mathrm{P}<0.01$ vs control.

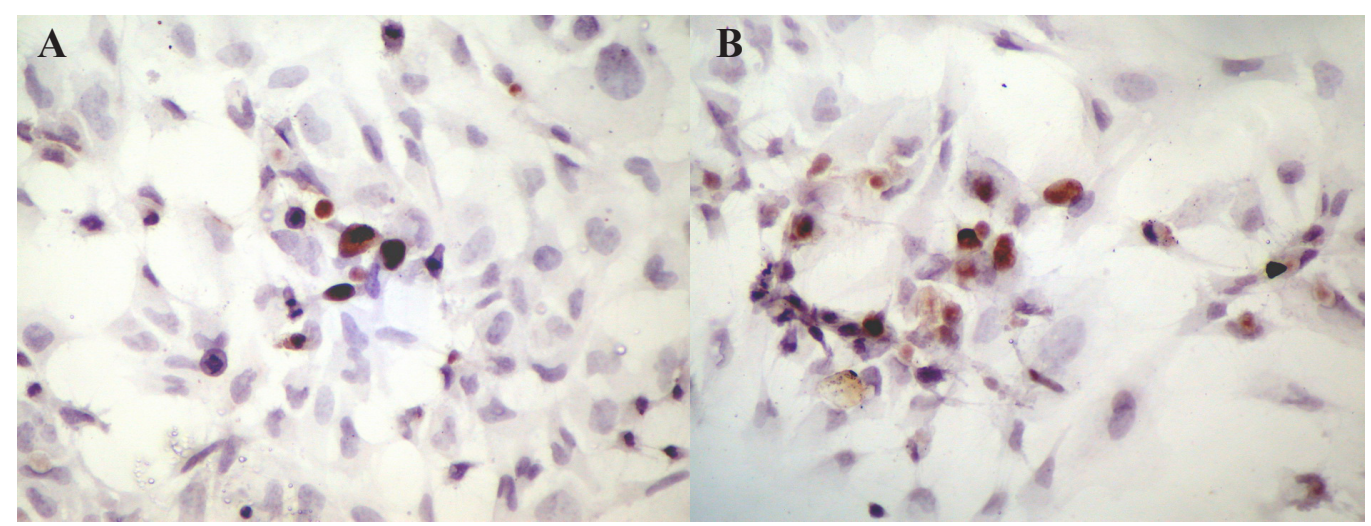

Figure 2. A. PCNA expression of HFE-145: DAB dyeing: $12 \mathrm{~h}$ after simulated weightlessness (200X). B. PCNA expression of HFE-145: DAB dyeing: $12 \mathrm{~h}$ in the control group (200X).

\section{Changes in the cell cycle after simulated weightlessness}

Compared with control cells, the cell cycles of SGC-7901 cells in the 12, 24, and 36 
$\mathrm{h}$ groups did not change significantly, but the cells in the $\mathrm{G}_{0}+\mathrm{G}_{1}$ phases in the 48 and $72 \mathrm{~h}$ groups increased significantly (Table $3 ; \mathrm{P}<0.01$ and $\mathrm{P}<0.05$ ); accordingly, the cells in $\mathrm{S}+$ $\mathrm{G}_{2}+\mathrm{M}$ phase decreased significantly (Table $3 ; \mathrm{P}<0.01$ and $\mathrm{P}<0.05$ ). The cell cycles for cell line HFE-145 in the 2, 36, 48, and $72 \mathrm{~h}$ groups did not change significantly, but the cells in $\mathrm{G}_{0}$ $+\mathrm{G}_{1}$ phase in the $12 \mathrm{~h}$ group increased significantly (Table 3; P $<0.05$ ) and the cells in $\mathrm{S}+\mathrm{G}_{2}$ $+\mathrm{M}$ phase decreased significantly (Table $3 ; \mathrm{P}<0.05$ ).

Table 3. Cell cycle of SGC-7901 and HFE-145 cells during simulated weightlessness.

\begin{tabular}{lllcrrrr}
\hline Cell & Group & Phase & $12 \mathrm{~h}$ & $24 \mathrm{~h}$ & \multicolumn{1}{c}{$36 \mathrm{~h}$} & $48 \mathrm{~h}$ & $72 \mathrm{~h}$ \\
\hline SGC-7901 $(\mathrm{N}=6)$ & Control & $\mathrm{G}_{0}+\mathrm{G}_{1}$ & $46.8 \pm 3.76$ & $57.2 \pm 4.33$ & $63.7 \pm 1.82$ & $55.8 \pm 2.29$ & $57.3 \pm 3.49$ \\
& Rotating & & $44.0 \pm 5.04$ & $63.2 \pm 3.98$ & $67.5 \pm 4.23$ & $71.0 \pm 3.92^{* *}$ & $67.0 \pm 1.98^{*}$ \\
& Control & $\mathrm{G}_{2}+\mathrm{M}$ & $13.0 \pm 5.85$ & $19.1 \pm 5.47$ & $3.7 \pm 1.61$ & $3.1 \pm 1.07$ & $4.1 \pm 2.21$ \\
& Rotating & & $11.4 \pm 5.32$ & $9.4 \pm 3.07$ & $4.7 \pm 1.53$ & $11.1 \pm 6.40$ & $5.7 \pm 1.89$ \\
& Control & $\mathrm{S}$ & $40.1 \pm 2.95$ & $23.8 \pm 2.67$ & $32.6 \pm 2.04$ & $41.2 \pm 2.89$ & $38.6 \pm 4.87$ \\
& Rotating & & $44.5 \pm 3.80$ & $27.4 \pm 2.55$ & $36.3 \pm 1.82$ & $17.9 \pm 5.98$ & $27.2 \pm 2.98$ \\
& Control & $\mathrm{G}_{2}+\mathrm{M}+\mathrm{S}$ & $53.2 \pm 3.76$ & $42.8 \pm 4.33$ & $41.4 \pm 2.85$ & $44.2 \pm 2.29$ & $42.7 \pm 3.44$ \\
& Rotating & & $56.0 \pm 5.04$ & $36.8 \pm 3.95$ & $32.5 \pm 4.26$ & $29.0 \pm 3.97 * *$ & $33.0 \pm 1.98^{*}$ \\
HFE-145 (N=5) 5) & Control & $\mathrm{G}_{0}+\mathrm{G}_{1}$ & $36.9 \pm 1.21$ & $51.3 \pm 5.74$ & $58.5 \pm 2.76$ & $56.1 \pm 3.99$ & $62.5 \pm 4.21$ \\
& Rotating & & $48.5 \pm 4.38^{*}$ & $52.9 \pm 4.05$ & $64.9 \pm 3.28$ & $60.5 \pm 5.92$ & $70.2 \pm 2.37$ \\
& Control & $\mathrm{G}_{2}+\mathrm{M}$ & $20.3 \pm 0.78$ & $14.6 \pm 3.76$ & $12.4 \pm 4.20$ & $5.1 \pm 3.69$ & $5.3 \pm 1.67$ \\
& Rotating & & $19.3 \pm 5.15$ & $14.8 \pm 2.60$ & $7.7 \pm 2.70$ & $6.8 \pm 2.08$ & $7.2 \pm 1.16$ \\
& Control & $\mathrm{S}$ & $42.6 \pm 1.49$ & $34.1 \pm 2.23$ & $29.0 \pm 3.23$ & $38.8 \pm 1.23$ & $32.2 \pm 5.06$ \\
& Rotating & & $32.2 \pm 7.75$ & $32.3 \pm 3.07$ & $27.4 \pm 3.11$ & $32.7 \pm 4.01$ & $22.6 \pm 2.39$ \\
& Control & $\mathrm{G}_{2}+\mathrm{M}+\mathrm{S}$ & $62.9 \pm 1.22$ & $48.7 \pm 5.74$ & $41.4 \pm 2.85$ & $43.9 \pm 3.99$ & $37.5 \pm 4.20$ \\
& Rotating & & $51.5 \pm 4.38^{*}$ & $47.1 \pm 4.08$ & $35.1 \pm 3.28$ & $39.5 \pm 5.92$ & $29.8 \pm 2.36$ \\
\hline
\end{tabular}

Data are reported as means $\pm \mathrm{SD} . * \mathrm{P}<0.05$ and $* * \mathrm{P}<0.01$ vs control.

\section{Cell apoptosis after simulated weightlessness}

Compared with control cells, the apoptosis index of cell line SGC-7901 in the 12, 24, 36 , and $48 \mathrm{~h}$ groups did not change significantly, but increased significantly in the $72 \mathrm{~h}$ group (Figure $3 \mathrm{~A}$ and $\mathrm{B}$, Table 4; $\mathrm{P}<0.01$ ). The apoptosis index of cell line HFE-145 in the 24, 36, 48 , and $72 \mathrm{~h}$ groups did not change significantly, but increased significantly in the $12 \mathrm{~h}$ group (Figure 4A and B, Table 4; $\mathrm{P}<0.05$ ).

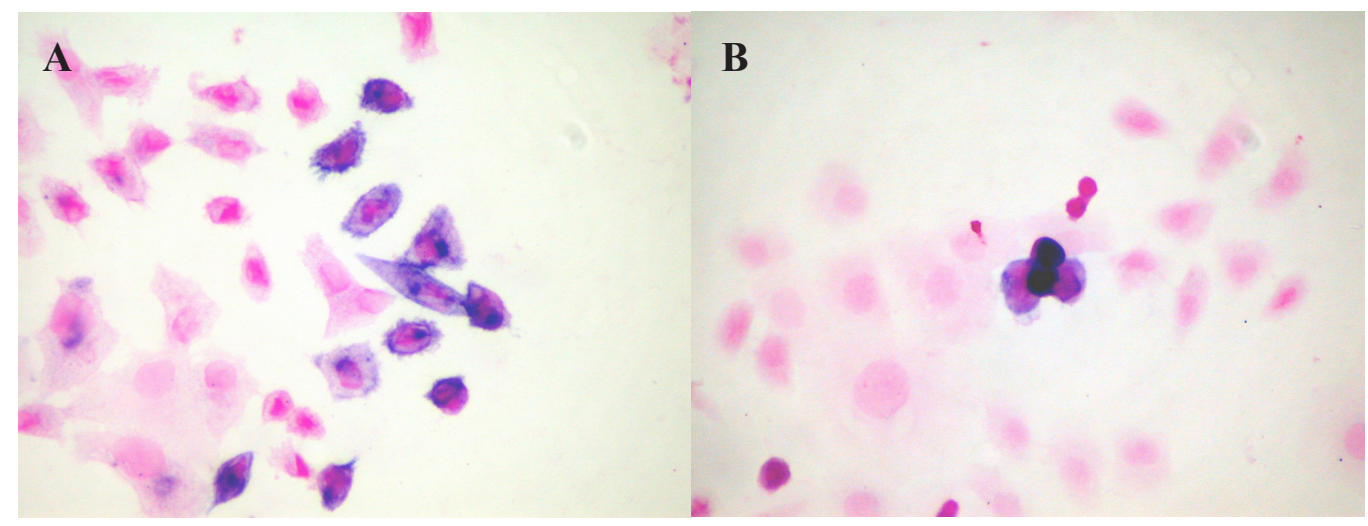

Figure 3. A. Apoptosis of SGC-7901: NBT/BCIP dyeing: $72 \mathrm{~h}$ after simulated weightlessness (200X). B. Apoptosis of SGC-7901: NBT/BCIP dyeing: $72 \mathrm{~h}$ in the control group (200X). 
Table 4. Apoptosis index of SGC-7901 and HFE-145 cells during simulated weightlessness.

\begin{tabular}{|c|c|c|c|c|c|c|}
\hline Cell & Group & $12 \mathrm{~h}$ & $24 \mathrm{~h}$ & $36 \mathrm{~h}$ & $48 \mathrm{~h}$ & $72 \mathrm{~h}$ \\
\hline \multirow{2}{*}{ SGC-7901 $(\mathrm{N}=6)$} & Control & $9.6 \pm 1.21$ & $4.9 \pm 0.74$ & $4.7 \pm 0.57$ & $4.4 \pm 1.15$ & $4.8 \pm 1.02$ \\
\hline & Rotating & $9.9 \pm 0.92$ & $4.8 \pm 0.81$ & $5.7 \pm 0.77$ & $6.9 \pm 0.48$ & $8.9 \pm 0.56^{*}$ \\
\hline \multirow[t]{2}{*}{ HFE-145 (N = 5) } & Control & $4.7 \pm 0.22$ & $3.9 \pm 0.57$ & $4.6 \pm 0.83$ & $3.3 \pm 0.68$ & $5.1 \pm 1.05$ \\
\hline & Rotating & $6.3 \pm 0.52^{* *}$ & $4.6 \pm 0.68$ & $5.3 \pm 0.84$ & $4.3 \pm 0.79$ & $5.4 \pm 0.84$ \\
\hline
\end{tabular}

Data are reported as means $\pm \mathrm{SD} . * * \mathrm{P}<0.05$ and $* \mathrm{P}<0.01$ vs control.

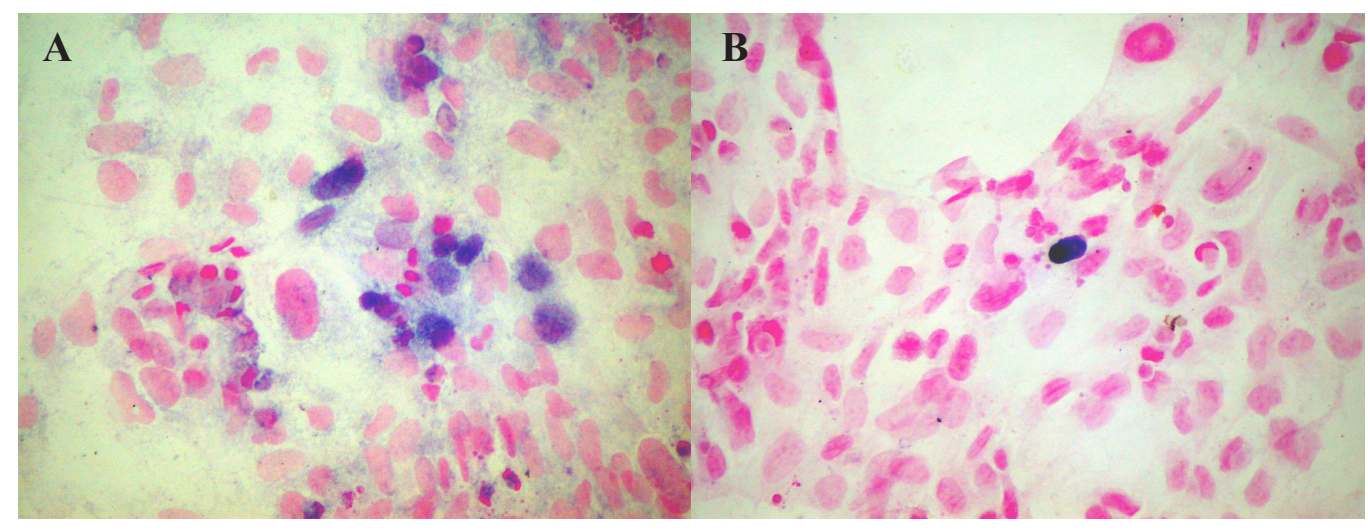

Figure 4. A. Apoptosis of HFE-145: NBT/BCIP dyeing: $12 \mathrm{~h}$ after simulated weightlessness (200X). B. Apoptosis of HFE-145: NBT/BCIP dyeing: $12 \mathrm{~h}$ in the control group (200X).

\section{DISCUSSION}

In this study, we examined biocharacteristic changes in gastric cancer cells by simulating weightlessness using a clinostat. SGC-7901 cells showed changes in cellular morphology and biological characteristics during clinostat-simulated weightlessness for $72 \mathrm{~h}$, but HFE-145 cells only changed after $12 \mathrm{~h}$ and then adapted to simulated weightlessness. We found that the cellular morphology of SGC-7901 cells was altered over time within 3 days, cell conversion from $\mathrm{G}_{1}$ phase to $\mathrm{S}$ phase was blocked, proliferation was inhibited at 48 and $72 \mathrm{~h}$, and the apoptosis index was increased at $72 \mathrm{~h}$. Similar changes were observed for HFE-145 cells in the $12 \mathrm{~h}$ group after being subjected to simulated weightlessness, but no significant change was observed after $12 \mathrm{~h}$ compared to control cells.

The reason that cells are sensitive to weightlessness remains unknown. Weightlessness can affect many aspects of cellular physics, including water pressure of the cytocyst, sedimentation of the organelle, and the water conduction. These physical phenomena can influence cell shape, metabolism, movement, and exocrine and signal conduction, either directly or indirectly (Freed and Vunjak-Novakovic, 2002). Previous studies have suggested that cytoskeleton and membrane structural changes occur when cells are subjected to weightlessness (Ingber, 1999; Infanger et al., 2004, 2006a; Kumei et al., 2006). A corresponding redistribution of the cell structure occurs to maintain balance. DNA is also sensitive to weightlessness as the DNA spindle itself is a balanced structure. Changes in nuclear structure have been observed in previous weightlessness studies (Ingber, 1999; Hughes-Fulford et al., 2006). Such redistribu- 
tion can affect cell junctions and the extracellular matrix, as well as cause a series of reactions in signal transduction, inducing changes in gene expression, which ultimately manifest as changes in biological characteristics (Ingber, 1999; Kumei et al., 2007).

SGC-7901 cells are gastric carcinoma cells that grow malignantly and lose cell stability. Thus, they are affected by changes in extracellular conditions. In the present study, when the cell shape changed within 3 days, cellular biological characteristics were also altered. However, HFE-145 cells showed effects only in the $12 \mathrm{~h}$ group, and no significant change was observed after $12 \mathrm{~h}$ compared with control cells. HFE-145 cells may have adapted after $12 \mathrm{~h}$ because of their fast restructuring and better adaptive capacity. Thus, a new dynamic balance could be induced rather quickly.

There have been no previous studies examining gastric carcinoma and normal cells under weightlessness or simulated weightlessness. However, many studies have examined other human or animal cells under these conditions. Cell morphology changes were observed under weightlessness or simulated weightlessness in human osteoblast cells (Yuge et al., 2003) and erythrocytes from humans and rabbits (Shen et al., 1997). However, no significant changes have been observed for monkey kidney cells (Sato et al., 2001).

Regarding the biological characteristics of carcinoma cells, weightlessness or simulated weightlessness can cause slower growth, lower proliferation, and better differentiation in human prostate cells, as well as activation of second messengers and reciprocity between different signal transduction passages (Clejan et al., 2001). It can also cause early apoptosis, redistribution of mitochondria, and destruction of microtubules in human thyroid carcinoma cells (Kossmehl et al., 2002). The cytoskeleton, DNA structure, and microtubules of the human breast cancer cell line MCF-7 changed during space flight due to lower proliferation and blockage of the cell cycle (Vassy et al., 2003). However, there was less apoptosis and increased mitosis observed in human pancreas carcinoma cells under simulated weightlessness using a clinostat (Nakamura et al., 2002). Taga et al. (2006) indicated that the simulated microgravity conditions may have altered murine B16-F10 melanoma cell characteristics and enhanced their invasive properties. It is possible that the microgravity analog culture environment selected highly tumorigenic cells for survival despite the decreased overall growth in the microgravity analog.

Regarding the biological characteristics of normal cells, microgravity could block the cell cycle in human osteoblast cells (Blaber et al., 2013) and potentiate stem cell proliferation, while sustaining the capacity for differentiation (Yuge et al., 2006). Cell cycle control proteins in human T lymphocytes showed altered microgravity (Thiel et al., 2012). Microgravity caused increased apoptosis in human thyroid cells (Kossmehl et al., 2003) and human endothelial cells (Infanger et al., 2006b). Simulated microgravity decreased apoptosis in fetal fibroblasts (Beck et al., 2012). However, proliferation of rat jejunum mucosal cells (Sawyer et al., 1992) and apoptosis of human erythrocytes (Sytkowski and Davis, 2001) were not affected by weightlessness. Furthermore, cultured glial C6 cells initiated apoptosis $30 \mathrm{~min}$ after the initiation of simulated weightlessness using a clinostat; however, the proportion of apoptotic cells decreased gradually after 20 or $32 \mathrm{~h}$ (Uva et al., 2002). In contrast, Bucaro et al. (2007) concluded that osteoblast apoptosis is not induced by vector-averaged gravity.

The discrepancies between our study and previous studies may have resulted from differences in cell types or the use of different conditions and time of weightlessness. In our study, we used a clinostat to simulate weightlessness (Klaus, 2001). Samples are driven to 
revolve around horizontal axes. The direction of gravity changes continuously, corresponding to the samples, so that the samples are not able to respond to gravity under certain rotating speeds. However, a clinostat cannot be used to completely simulate space conditions, and is different from other microgravity instruments. Thus, our results are applicable only for 3-daysimulated weightlessness conditions using a clinostat.

In summary, we found that cellular morphology changes, cell cycle blockage, increasing proliferation, and less apoptosis occurred in the human gastric carcinoma cell line SGC-7901 at $72 \mathrm{~h}$ under simulated weightlessness conditions using a clinostat. However, the same changes occurred in the human gastric normal cell line HFE-145 after only $12 \mathrm{~h}$ of simulated weightless, and there were no significant differences compared with control cells subsequently. This indicates that 3-day-simulated weightlessness using a clinostat can inhibit gastric carcinoma cells and has little influence on normal gastric cells. Thus, weightlessness or simulated weightlessness may be a physical factor that can restrain gastric carcinoma cells. Additional studies are needed to confirm this hypothesis. For instance, prolonging the time of simulated weightlessness, examination of other gastric cancer and gastric epithelial cell lines, observation in actual weightlessness conditions, and molecular-level studies should be conducted. Simulated weightlessness provides a new model for cellular studies, which would enable deeper exploration and study of the laws of the initiation and development of human gastric cells.

\section{REFERENCES}

Beck M, Tabury K, Moreels M, Jacquet P, et al. (2012). Simulated microgravity decreases apoptosis in fetal fibroblasts. Int. J. Mol. Med. 30: 309-313.

Blaber EA, Dvorochkin N, Lee C, Alwood JS, et al. (2013). Microgravity induces pelvic bone loss through osteoclastic activity, osteocytic osteolysis, and osteoblastic cell cycle inhibition by CDKN1a/p21. PLoS One 8: e61372.

Bucaro MA, Zahm AM, Risbud MV, Ayyaswamy PS, et al. (2007). The effect of simulated microgravity on osteoblasts is independent of the induction of apoptosis. J. Cell Biochem. 102: 483-495.

Clejan S, O'Connor K and Rosensweig N (2001). Tri-dimensional prostate cell cultures in simulated microgravity and induced changes in lipid second messengers and signal transduction. J. Cell Mol. Med. 5: 60-73.

Freed LE and Vunjak-Novakovic G (2002). Spaceflight bioreactor studies of cells and tissues. Adv. Space Biol. Med. 8: 177-195.

Hughes-Fulford M (2001). Changes in gene expression and signal transduction in microgravity. J. Gravit. Physiol. 8: 1-4.

Hughes-Fulford M, Rodenacker K and Jutting U (2006). Reduction of anabolic signals and alteration of osteoblast nuclear morphology in microgravity. J. Cell Biochem. 99: 435-449.

Infanger M, Kossmehl P, Shakibaei M, Schulze-Tanzil G, et al. (2004). Longterm conditions of mimicked weightlessness influences the cytoskeleton in thyroid cells. J. Gravit. Physiol. 11: 169-172.

Infanger M, Kossmehl P, Shakibaei M, Bauer J, et al. (2006a). Simulated weightlessness changes the cytoskeleton and extracellular matrix proteins in papillary thyroid carcinoma cells. Cell Tissue Res. 324: 267-277.

Infanger M, Kossmehl P, Shakibaei M, Baatout S, et al. (2006b). Induction of three-dimensional assembly and increase in apoptosis of human endothelial cells by simulated microgravity: impact of vascular endothelial growth factor. Apoptosis 11: 749-764.

Ingber D (1999). How cells (might) sense microgravity. FASEB J. 13 (Suppl): S3-S15.

Klaus DM (2001). Clinostats and bioreactors. Gravit. Space Biol. Bull. 14: 55-64.

Kossmehl P, Shakibaei M, Cogoli A, Pickenhahn H, et al. (2002). Simulated microgravity induces programmed cell death in human thyroid carcinoma cells. J. Gravit. Physiol. 9: 295-296.

Kossmehl P, Shakibaei M, Cogoli A, Infanger M, et al. (2003). Weightlessness induced apoptosis in normal thyroid cells and papillary thyroid carcinoma cells via extrinsic and intrinsic pathways. Endocrinology 144: 4172-4179.

Kumei Y, Morita S, Katano H, Akiyama H, et al. (2006). Microgravity signal ensnarls cell adhesion, cytoskeleton, and matrix proteins of rat osteoblasts: osteopontin, CD44, osteonectin, and alpha-tubulin. Ann. N. Y. Acad. Sci. 1090: 311-317.

Genetics and Molecular Research 13 (3): 6060-6069 (2014)

CFUNPEC-RP www.funpecrp.com.br 
Kumei Y, Shimokawa H, Ohya K, Katano H, et al. (2007). Small GTPase Ras and Rho expression in rat osteoblasts during spaceflight. Ann. N. Y. Acad. Sci. 1095: 292-299.

Nakamura K, Kuga H, Morisaki T, Baba E, et al. (2002). Simulated microgravity culture system for a 3-D carcinoma tissue model. Biotechniques 33: 1068-1076.

Sato A, Kumei Y, Sato K, Hongo T, et al. (2001). Studies on the effects of microgravity on the ultrastructure and function of cultured mammalian cells. Biol. Sci. Space 15 (Suppl): S61-S63.

Sawyer HR, Moeller CL, Phillips RW and Smirnov KL (1992). Proliferation of jejunal mucosal cells in rats flown in space. J. Appl. Physiol. 73: 148S-150S.

Shen X, Dong Q, Chen J, Meng J, et al. (1997). Erythrocyte deformation in simulated weightless human and rabbits. $J$. Gravit. Physiol. 4: 61-65.

Sytkowski AJ and Davis KL (2001). Erythroid cell growth and differentiation in vitro in the simulated microgravity environment of the NASA rotating wall vessel bioreactor. In Vitro Cell Dev. Biol. Anim. 37: 79-83.

Taga M, Yamauchi K, Odle J, Furian L, et al. (2006). Melanoma growth and tumorigenicity in models of microgravity. Aviat. Space Environ. Med. 77: 1113-1116.

Thiel CS, Paulsen K, Bradacs G, Lust K, et al. (2012). Rapid alterations of cell cycle control proteins in human T lymphocytes in microgravity. Cell Commun. Signal. 10: 1.

Uva BM, Masini MA, Sturla M, Bruzzone F, et al. (2002). Microgravity-induced apoptosis in cultured glial cells. Eur. J. Histochem. 46: 209-214.

Vassy J, Portet S, Beil M, Millot G, et al. (2003). Weightlessness acts on human breast cancer cell line MCF-7. Adv. Space Res. 32: 1595-1603.

Yuge L, Hide I, Kumagai T, Kumei Y, et al. (2003). Cell differentiation and p38(MAPK) cascade are inhibited in human osteoblasts cultured in a three-dimensional clinostat. In Vitro Cell Dev. Biol. Anim 39: 89-97.

Yuge L, Kajiume T, Tahara H, Kawahara Y, et al. (2006). Microgravity potentiates stem cell proliferation while sustaining the capability of differentiation. Stem. Cells Dev. 15: 921-929. 